Portland State University

PDXScholar

$5-11-1976$

\title{
An Exploration of the Familiar and Nostalgic
}

Laura Paul

Portland State University

Follow this and additional works at: https://pdxscholar.library.pdx.edu/open_access_etds

Part of the Fine Arts Commons, and the Painting Commons

Let us know how access to this document benefits you.

\section{Recommended Citation}

Paul, Laura, "An Exploration of the Familiar and Nostalgic" (1976). Dissertations and Theses. Paper 2572. https://doi.org/10.15760/etd.2569

This Thesis is brought to you for free and open access. It has been accepted for inclusion in Dissertations and Theses by an authorized administrator of PDXScholar. Please contact us if we can make this document more accessible: pdxscholar@pdx.edu. 
AN ABSTRACT OF THE THESIS OF Laure Paul for the Master of Fine Arts in painting presented May 11, 1976.

Title: An Exploration of the Fandilar and Nostalgic.

APPROVED BY MEHBERS OF THE THESIS COMMITTEE:
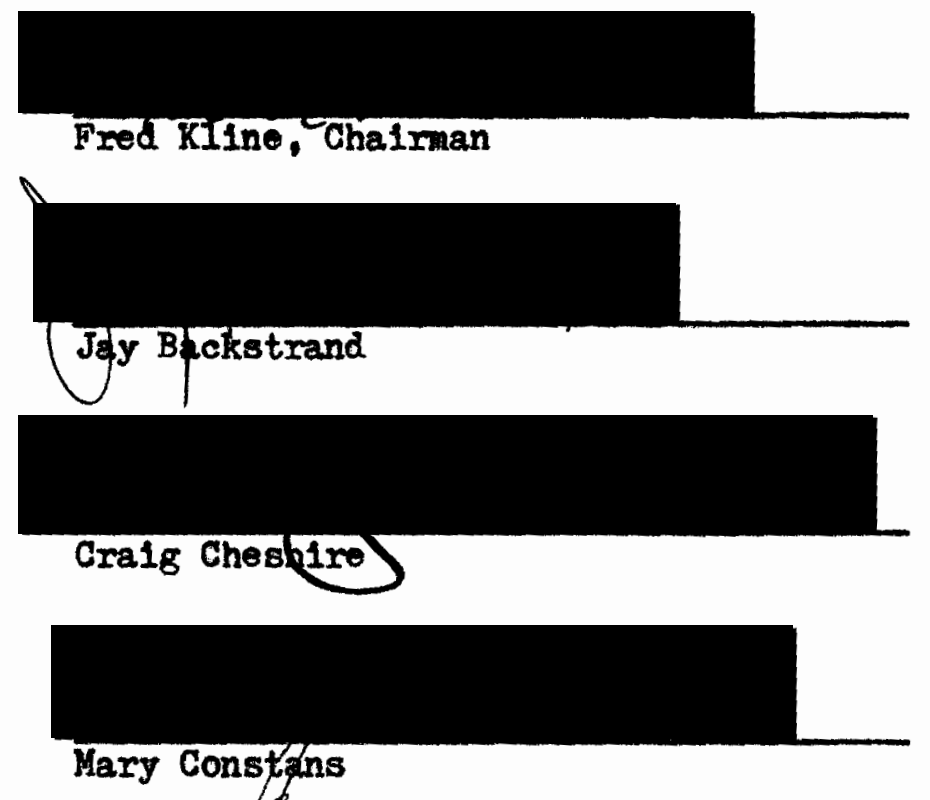

This thesis discusses forty peintings completed during the period of study from October of 1974 and presented at the Art and Architecture Gallery, May 26, 1976-June 11, 1976. 
AN EXPLORATION OF THE

FAMILIAR AND NOSTAIGIC

by

Laura Paul

A thesis submitted in partial fulfillment of the requirements for the degree of

MASTER OF FINE ARTS

in

PAINTING

Portland State UnIversity

1976 
TO THE OFFICE OF GRADUATE STUDIDS AND RESEARGH,

The members of the Comittee approve the thesis of Iaura Paul presented May 11, 1976.

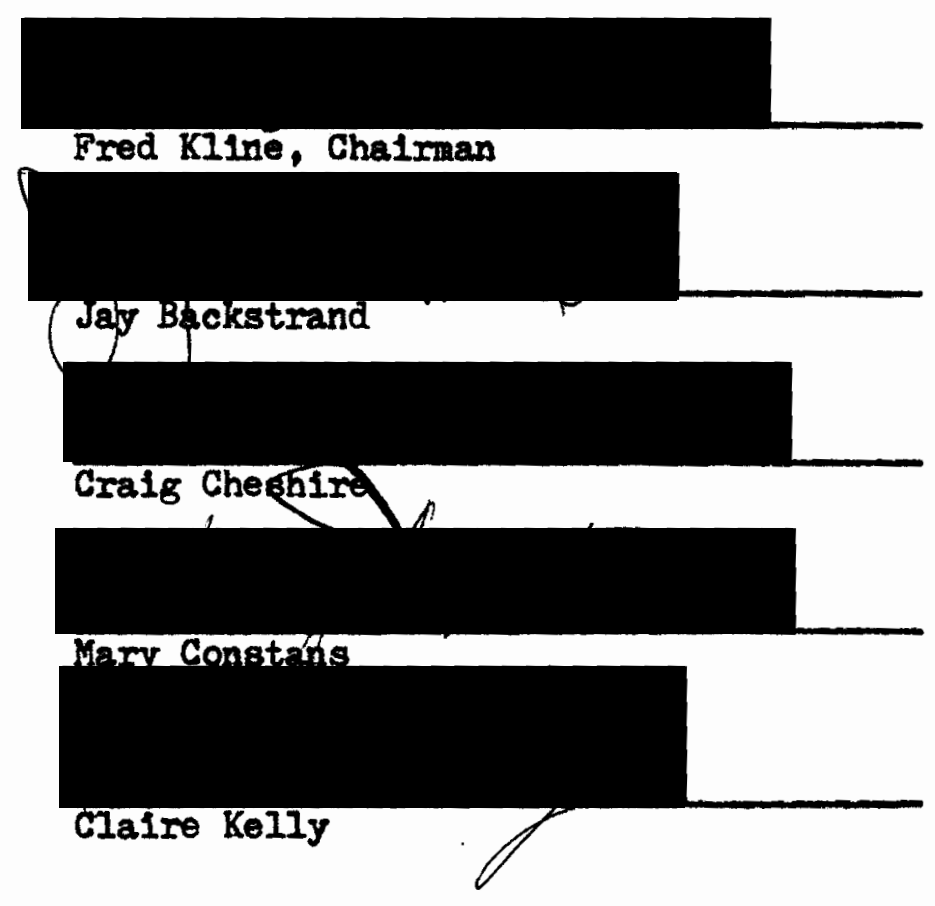

APFROVED,

Ieonard Kimbrell, Acting head Department of Art and Architecture Richard B. Halley, Acting Dean of Gradugte Studies and Research 
TABIE OF CONTENTS

IIST OF FIGURES ...................... Iv CHAPTER

I. INTRODUCTION . . . . . . . . . . . . I

II. DESCRIPTION AND ANAIYSIS OF THE PAINTING . . . . 2

III. CONCLUSION . . . . . . . . . . . . I7 
FIGURE

PAGE

I "Sitting on the Front Porch on a Summer Afternoon 3

II "Visitation Series $\# 8 "$

III "Visitation Series \#12" 5

IV "First Birthday 7?

V "First Birthday With Ten Stars" 7

VI "Six Sisters" 9

VII "Six Sisters in the Desert at N1ght". 9

VIII "Wy Sister and Myself on Old Brownle (Who Died Out at Pasture Instead of Being Sent to the Glue Factory)" 11

IX My Sister and Myself on Brownie (With Strange Object in the Air)" 11

X "Birds, Dogs, Palms, Sun" (detail) 13

XI "Alex's Mother when She Was In Hong Kong" I3

XII "Soo Chow Garden" 15

XII "Morning Table" 15

XIV "Moment in Time" 16

XV "Birds, Dogs, Palms, Sun" 16 
INTRODUCTION

For some time I have been fascinated by the potential that paintings have in their ability to develop a feeling of recognition between the situation of a painting and the memories of the audience. This body of work represents my attempt to use paintings to evoke a feeling of recognition in my audience.

Old music provides a good analogy to the purpose behind my work. Replaying a song from the $40^{\prime} \mathrm{s}$ will elicit the memories of an audience who grew up with that tune. One specific melody can trigger a variety of memories, the high school prom, leaving for the war, good and bad news. Since music waxes and wanes in popularity one song will typically remind an audience of a specific time in their lives which then brings out their individual memories. - In the same fashion I attempt to depict commonly experienced situations, ones which a majority of the audience has Iived through or at least recognizes as being familiar. This recognition of the famillar provides a touchstone of communication. This in turn provides the framework of the mood that I attempt to establish in each piece. 


\section{DESCRIPTION AND ANAIYSIS OF THE PAINTINGS}

"Sitting on the Front Porch on a Summer Afternoon" was the first exploration of my theme. The figure is actually sitting inside an open door with a bright summer day just outside. The title is taken from a Mairia Muldaur song which evokes in me a mood similar to the one I an trying to capture. I felt that the best way to communicate commonality, that is, the commonly experienced emotion, was to emphasize the situation and de-emphasize the individual. I did this by painting a scene with strong backlighting.

I attempted to carry this technique over to larger paintings but soon found that I was running into problems. I was painting large figures which were blurred and which were becoming shadowy non-people. This loss of individuality (no one can identify with a ghost), therefore led me into a new direction.

I began inviting acquaintances to my studio to pose for paintings. Visitation Series \#8 and \#12 are selected from this effort. I was now woring in a common setting with different subjects. The theme that I hoped was coming across was that different people sit and pose in a fashion characteristic of their personalities. Each character communicates a body language to the viewer who I hoped would say, "I know somebody like that".

Interesting aesthetic considerations began to surface. Although the background was the same (white studio wall, ochre studio floor with a wide black molding between the two), the colors used in these scenes varied with each different subject, I was reacting through color to the 


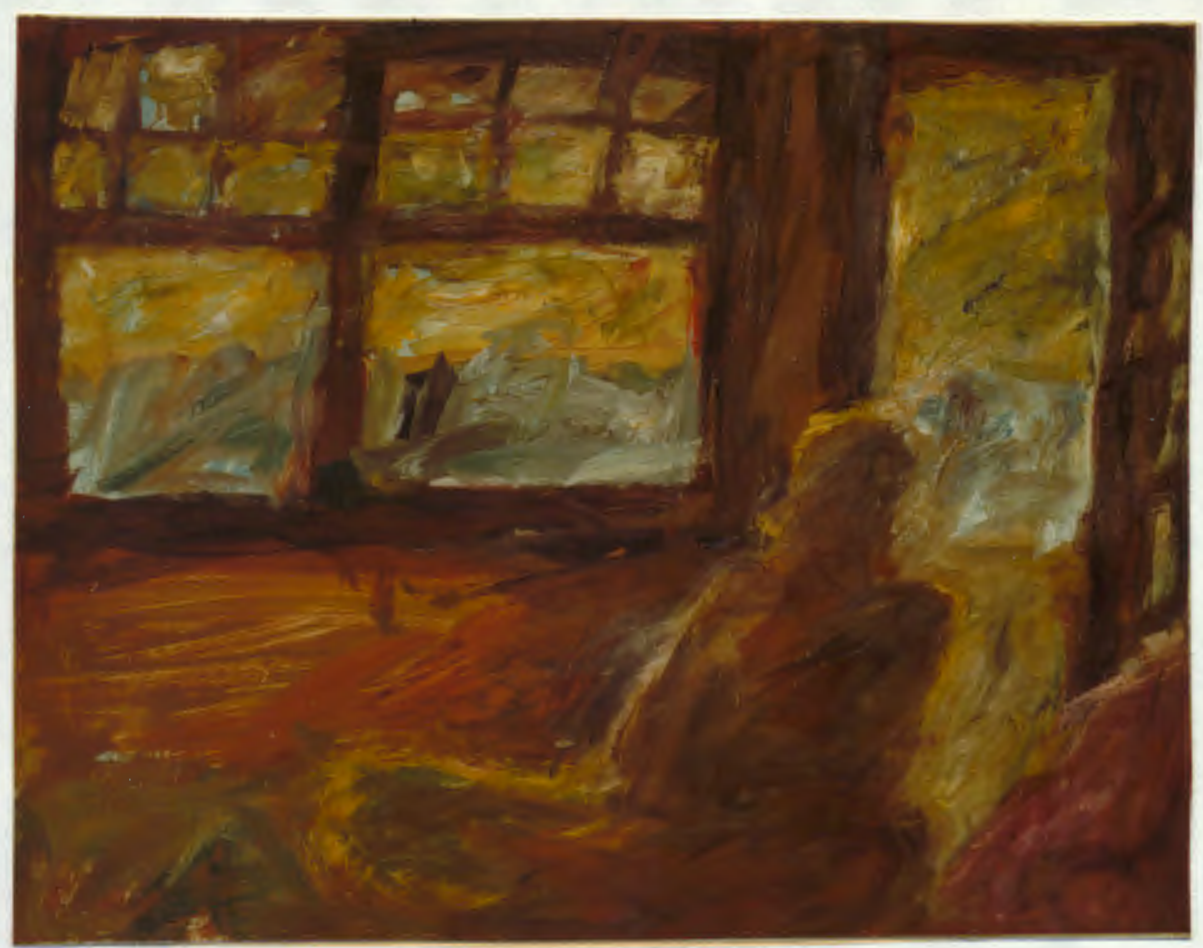

FIGURE I:

Sitting on the Front Porch on a Summer Afternoon 
mood evoked by differing personalities. I realized then that color was just as important to the capturing of a universal mood as was body language. Another aesthetic consideration $I$ was concerned with was the tension created between "Iooseness" in the form of loose painterly brushwork and "tightness" in the form of highly structured compositions.

Efforts to expand the visitation series proved unrewarding. I invited friends to the studio where $I$ took rapid succession photographs during conversation. In some cases I repeated the image as many as nine times and the overall piece took on the character of a comlc strip. Where one single work had captured an intimate view of a personality, multiple images expanded on that personality enough to confuse the viewer unfamiliar with the personality depicted. Working from iffe $I$ was able to condense into a single pose the twitches and subtle movements involved in sitting for a given period. The small paintings from life were more intimate and relaxed. I had taken great care to let the subject "settle-in" to a pose before I began. I would give no instructions on posing. Rather I would simply ask the subject to sit anywhere comfortable and begin a conversation to try to de-emphasize the posing aspect. Perhaps the presence of a camera influenced subjects in the multiple image series, making them stiffen and act more awkward than normal. At any rate, at this point I decided that for work to be personal to a viewer it had to first be personal and intimate to me, the artist.

The problem with the visitation series was that they were attempting to explore only one dimension of the human experience, i.e., old friends the audience has known. This obviously leaves out the vast panorama of human experience which was available to me so I changed direction again, 


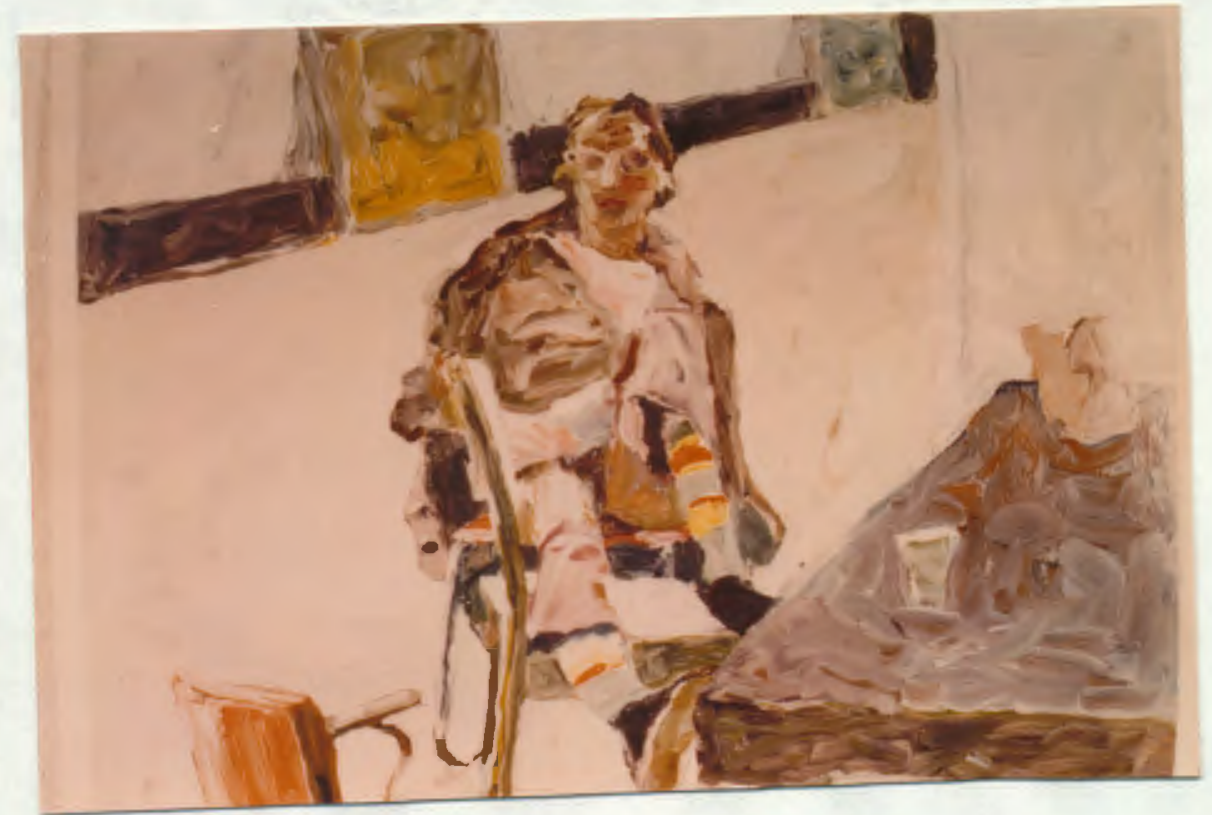

FIGURE II: Visitation Series \#8

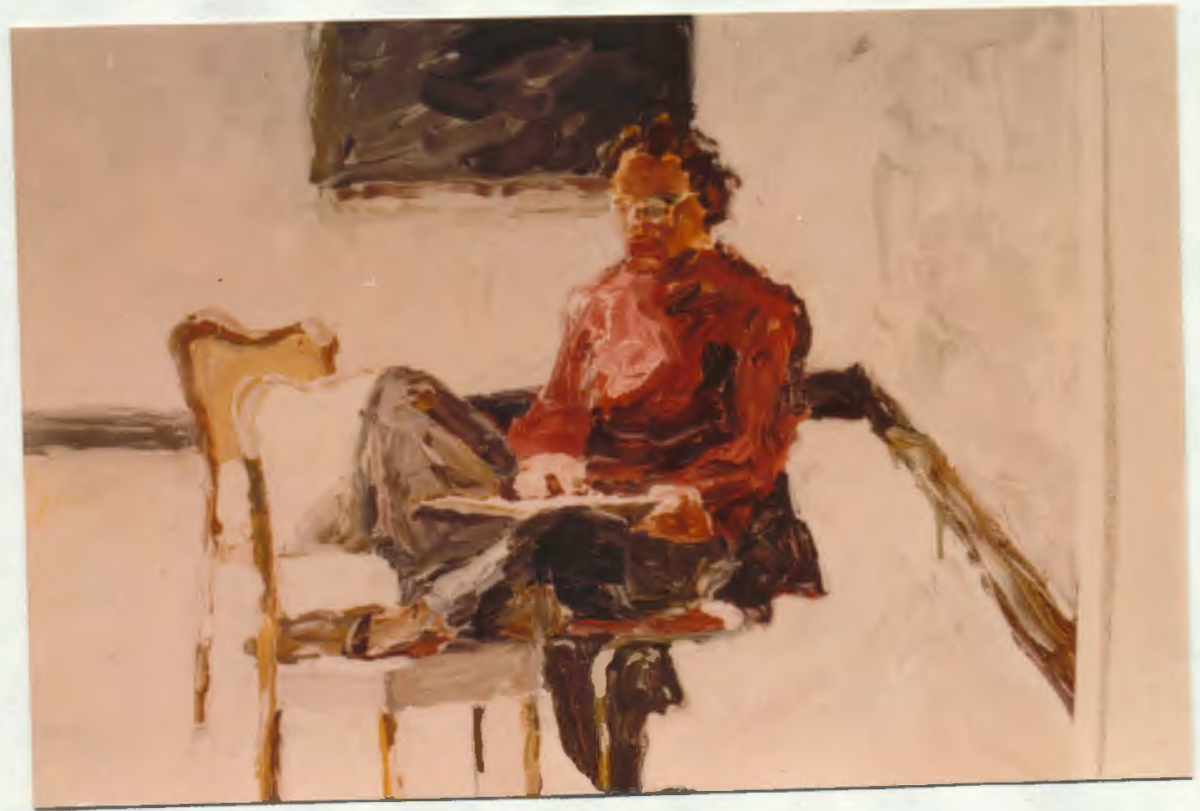

FIGURE III: Visitation Series \#12 
still seeking with the same purpose.

I turned to pictures from my family albums, for here $I$ felt that $I$ could draw on experiences common to all people. Since these photographs were from my past, or about people close to me, I felt that I could give my audience a painting filled with my own emotions. This "illuminating through emotional input" would hopefully add to the paintings effect.

I chose to work from old photographs with which I had a strong affinity. "First Birthday" was chosen not only for its commonality (almost everyone has a similar photograph in his family album), but also for the importance of the occasion. It is one of the first social-ceremonial traditions a young child experiences, Such an experience can be fun or terrifying. The bellowing expression on the child's face indicates that the latter was probably the case with me. The single view of such a scene did not communicate enough of the commonality that I was after however.

I wanted intimate memories to be evoked in my viewer, while at the same time making him aware that his experience was not unique or isolated. Therefore I looked to the technique of moving back from a situation to view it from a perspective that emphasized its significance as part of an ongoing whole. A person can view himself as only a small part within a room and that room as a spot in a bullding which is itself a part of a large city and so ongoing further away in perspective. I took the scene In "First Birthday" and reduced its size, placing it below a dark sky with ten scratched in stars. This may help the audience see that the intimate scene was occurring by itself while at the same time fitting in with the larger scheme of things.

Another consideration had been introduced at this point. In "First 


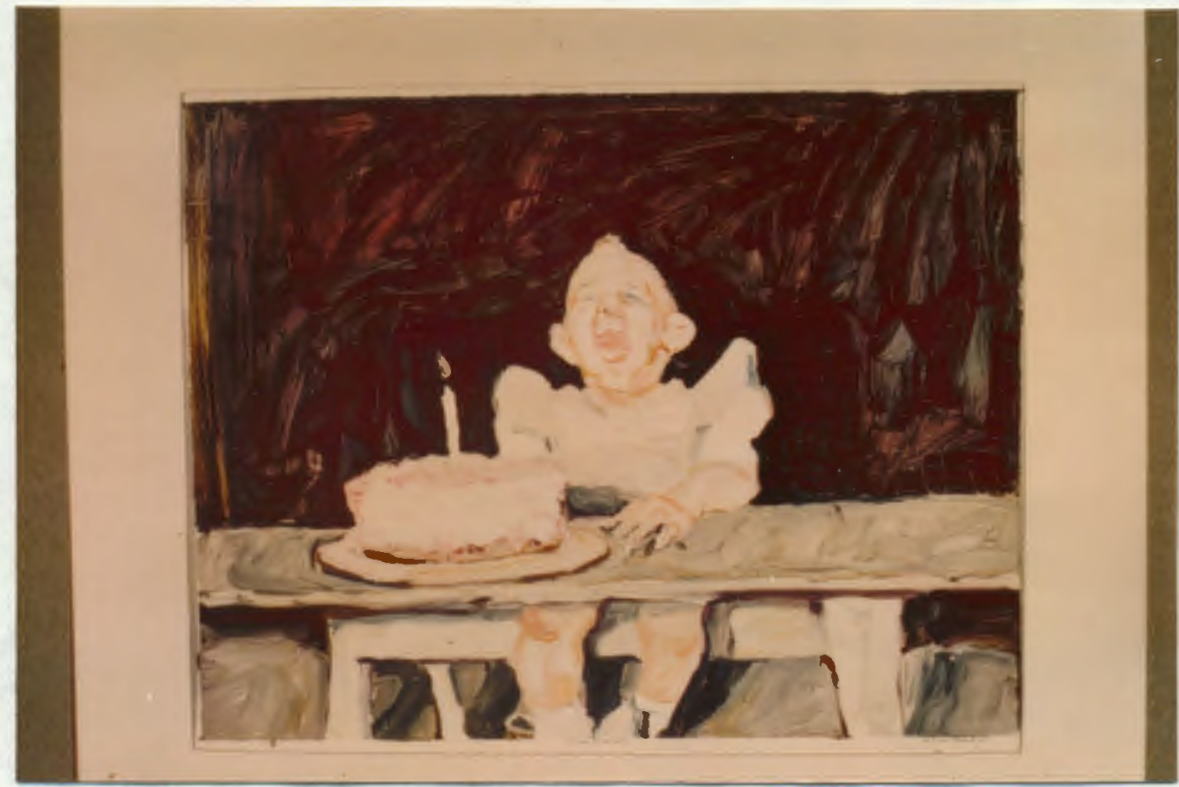

FIGURE IV: First Birthday

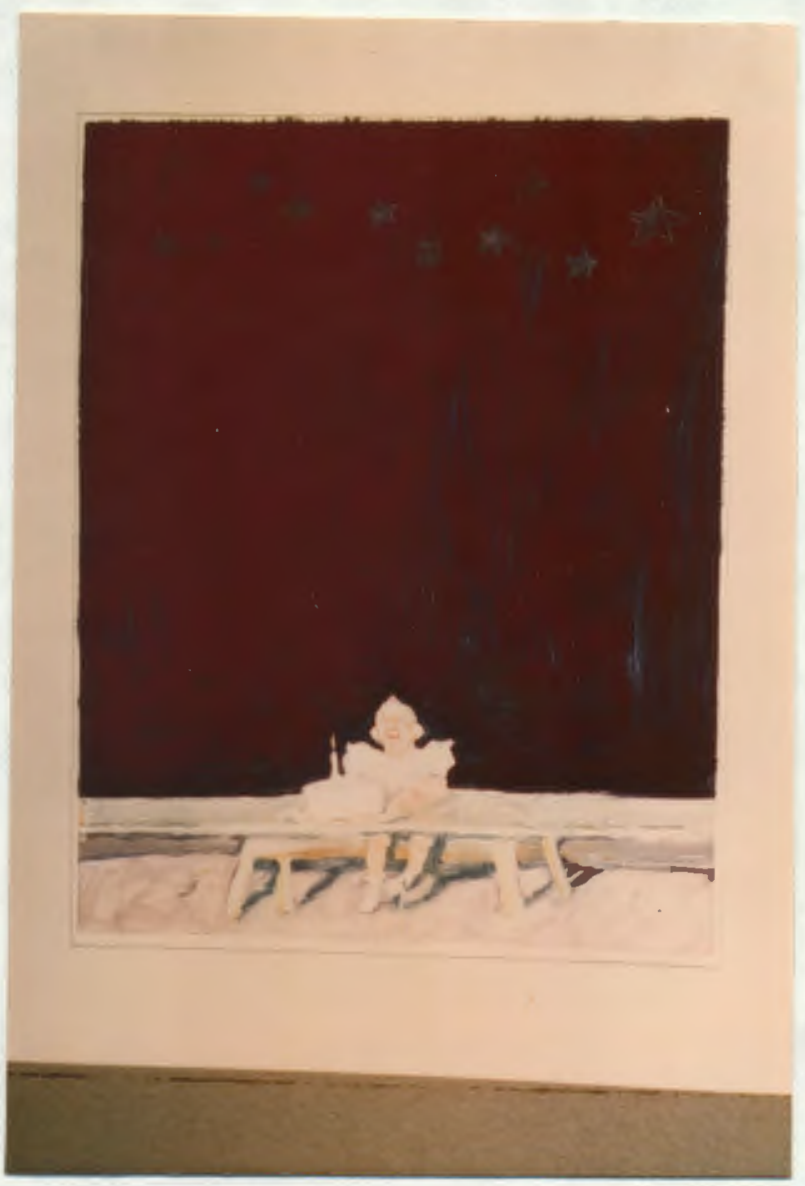

FIGURE V: First Birthday With Ten Stars 
Birthday with Ten Stars" I left the child painted as if illuminated by daylight, even though it was surrounded by night sky. This brought up an interesting philosophical consideration. The daylight lighting represented to me the "known", such as day-to-day intimate occurrences, (i,e., a birthday party). The dark sky or night background represented to me the "unknown", the experiences that the child had not yet Iived out. It is interesting that the young child viewed in such a setting sometimes evokes a feeling of fear in much of my audience (and myself) while a different subject matter depicted in the same environment (my grandmother and her five sisters, "Six Sisters in the Desert at Night"), does not evoke such fear. These women are seen in the twilight of their years. Standing together and not alone they tip the scale of time in that they have already experienced more than they will experience in the future. In other words they have just about made it across the unknown.

The dark sky backgrounds brought another aspect of personalization. By scratching into the wet, dark paint $I$ was able to add personal symbols that further illuminated my intimate experiences. An example of this can be seen in "My Sister and Myself On Old Brownie (Who Died out at Pasture Instead of Being Sent to the Glue Factory)". Four small stick horses are scratched into the sky with the names of each written above. These represent the stick horses that my father made us in our youth. Their presence in a work depicts two girls on a real horse alludes, in my mind, to the fact that stick horses took on a life-like existence in my fantacies since the real animal was included in my experience. The title itself represents a further attempt at personalization, expressing a child-like concern in the parenthesis, Elements of fantasy such as 


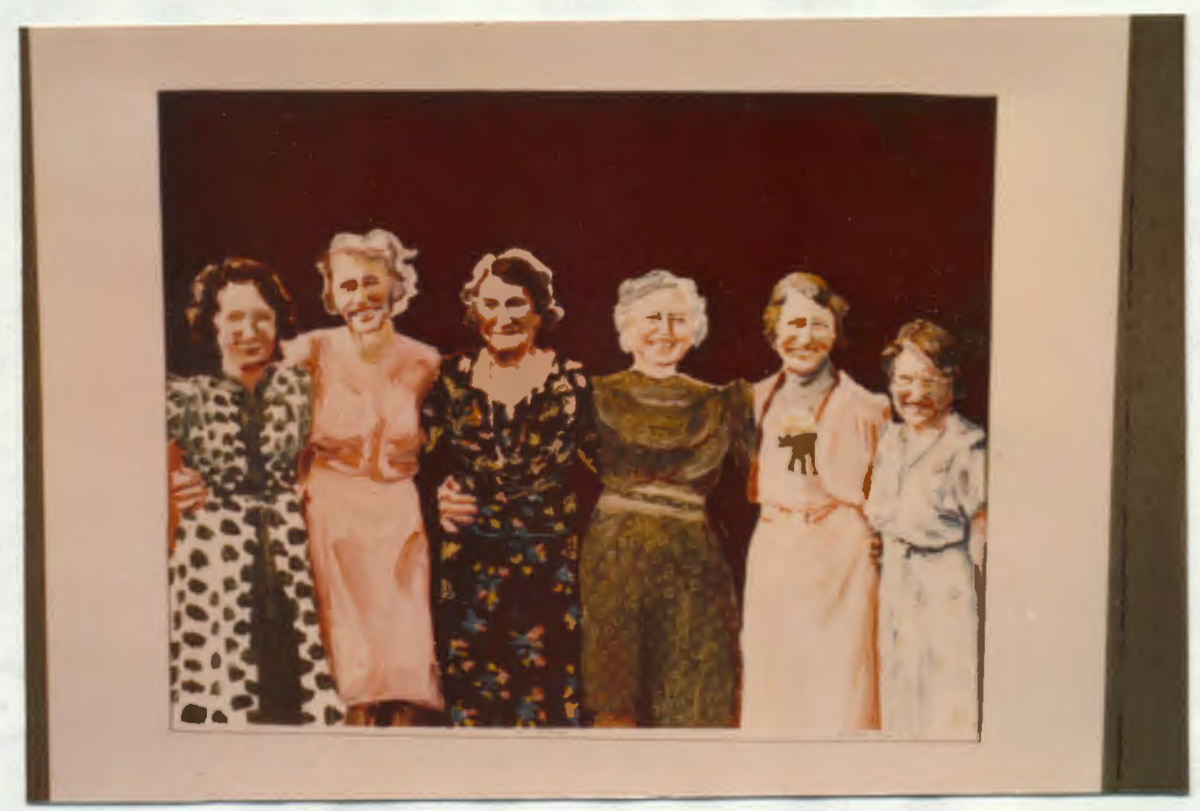

FIGURE VI: Six Sisters

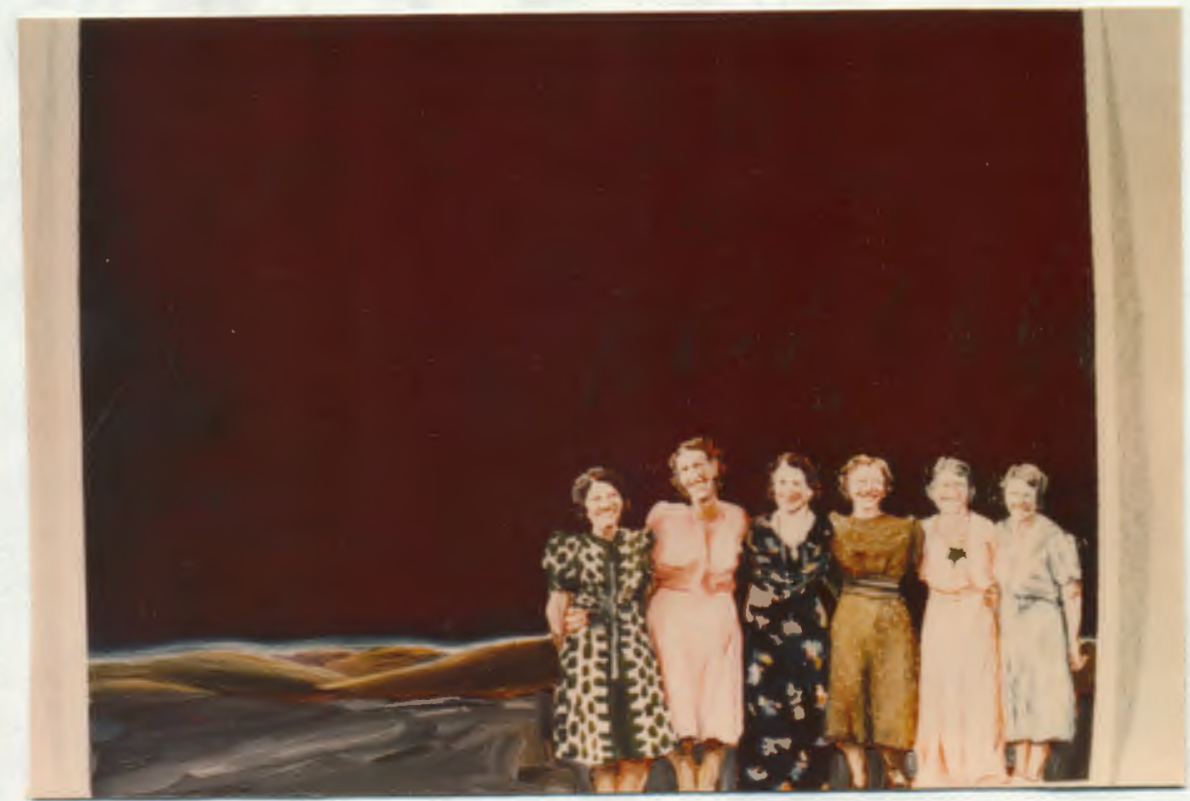

FIGURE VII: Six Sisters in the Desert at Night 
those included in this work and its companion piece, "My Sister and Myself With Strange Object in the Air" would hopefully evoke similar rememberances of personal fantasies in my audience.

There were several considerations that I worked on while doing the paintings described above. One was the economical use of brushwork for descriptive areas. In an area of descriptive detail such as the faces In "Six Sisters" I worked at using the fewest amount of paint strokes required to create the illusion of a person's face. Although this was often a lengthy process with many scraping outs and re-doings, I wanted the finished product to look fluid, as if it was just dashed off with comparative ease.

The second consideration that I worked through was in the integration of large flat areas of background with smaller tighter areas of detail. An example of this can be seen in "Father's Trophy". To integrate these two areas it was necessary to paint the background flat, using thinner paint. I often used wider brushes for this. To integrate these flat areas with areas of greater detail and smaller, thicker brush work I built up ridges of paint where the two areas met. I worked strokes from the more detailed areas out into the flatness in strategic places, allowing the stroke to run out and blend. This technique was in part influenced by careful examination of the work of Califomia painter Mel Ramos, seen on a trip to the Oakland Museum. Discovering this technique proved most helpful in working on the larger paintings that came after this experience. After exploring the subject matter of my own family album I turned to a logical second source, my husband's family album. His parents were English people who had grown up in pre W.W. II Hong Kong. Their photos 


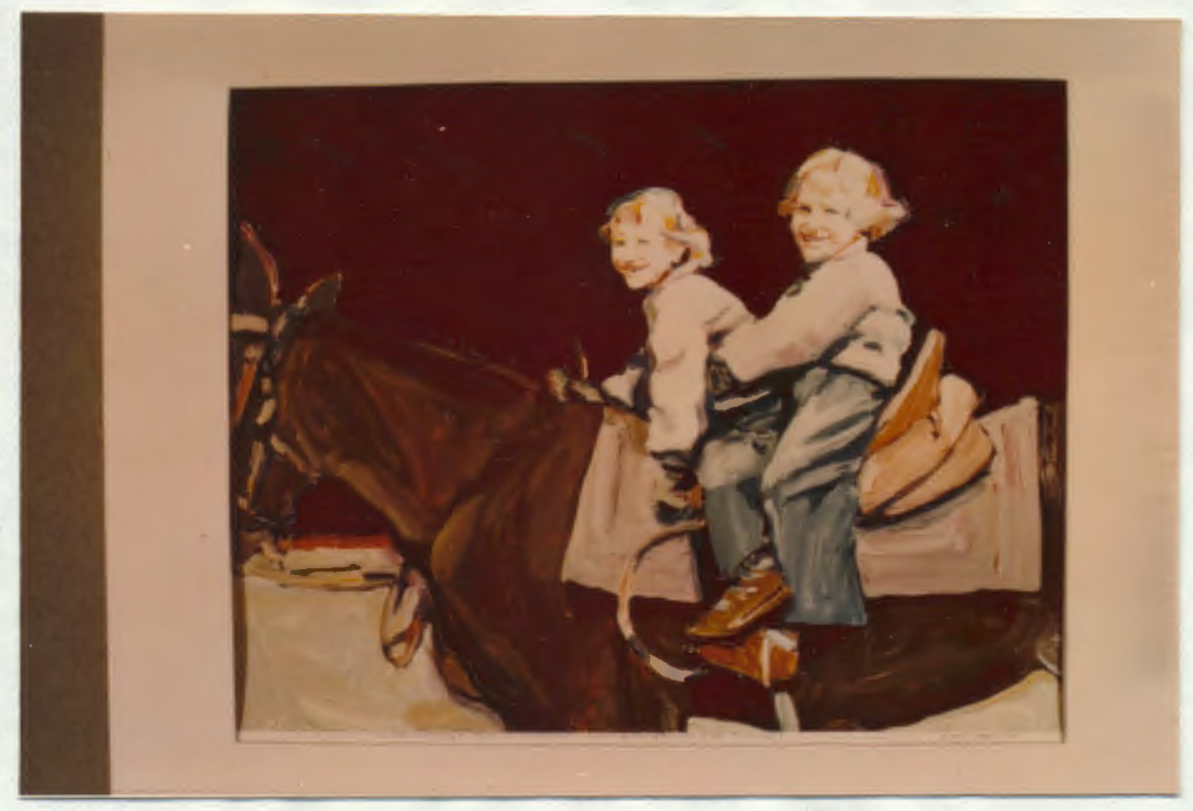

FIGURE VIII: My Sister and Myself on OId Bromie

(Who Died Out at Pasture Instead of Being Sent to the Glue Factory)

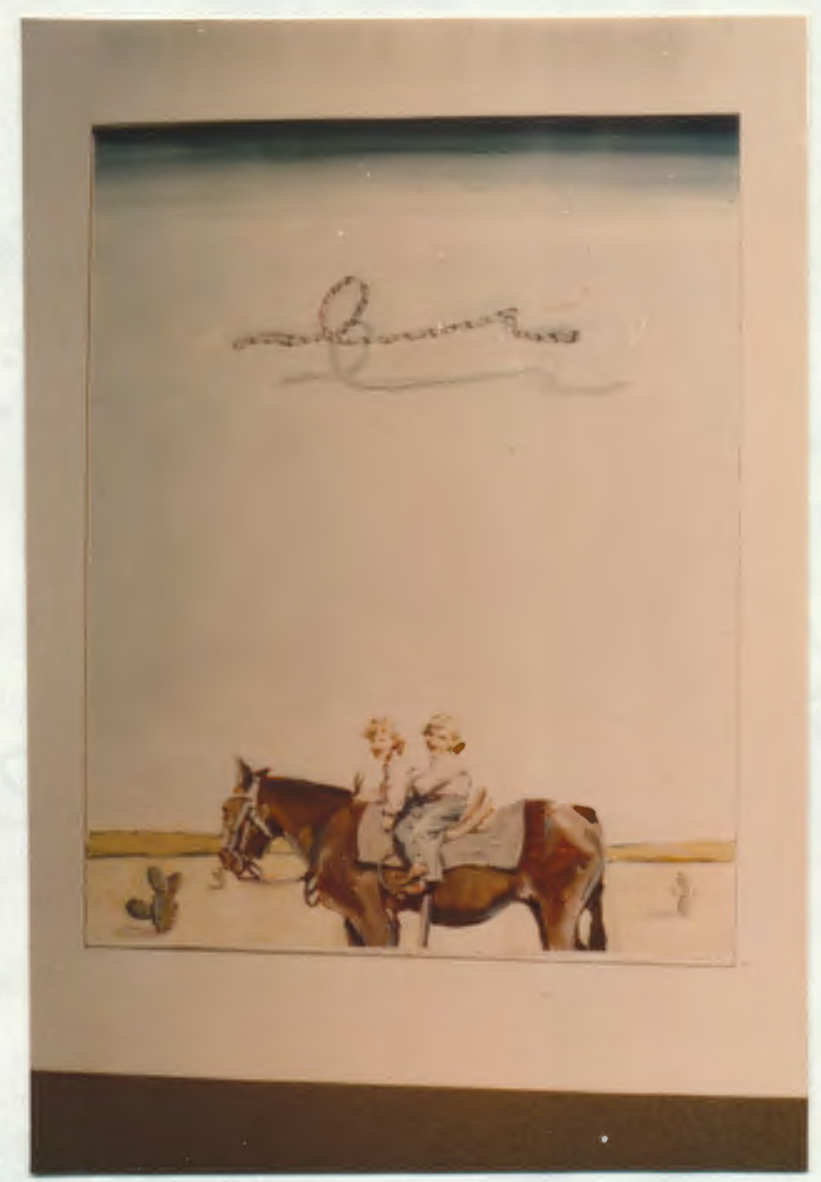

FIGURE IX: My Sister and Myself on Brownie (With Strange Object in the Air) 
from this period interested me for two reasons. The first was the strong Iighting contrasts found in these photos. Fong Kong is on a very sunny latitude and the strong sunlight caused shadow elements that worked welI compositionally as in "Alex's Mother When She Was in Hong Kong". The sunlight also created an atmosphere that I hoped my audience would relate to on an intimate scale. Oregonians especially seem to react strongly to the effects of the sun. This universal reaction to an environmental element (Sunshine) had been an important concem in my earlier work (Sitting on the Front Porch on a Summer's Afternoon), but I had not explored It any further until I began the Hong Kong series.

The second reason that these photos interested me was the chance to interpret my own feelings about this particular period in history. I was a third person viewing an important period in history via the mechanism of intimate photographs. Although I currentIy know my husband's parents, I know an Americanized version. Their experiences in Hong Kong are completely foreign to me.

Fre W.W. II Hong Kong was one of the last bastions of the British empire. The English, leasing their land from China for 99 years and carrying, with them their stern disciplines and rigid customs, defined their environment with their attitudes as much as with their military force.

The idyllic sunshine, the Chinese servants, and the feeling of the Iull before the storm served as the impetus for this series. The paintings were done with painterly brushwork that seem to vibrate when viewed up close. When the viewer stands back, however, these small movements disappear and the painting comes into focus. This tension in the work was 


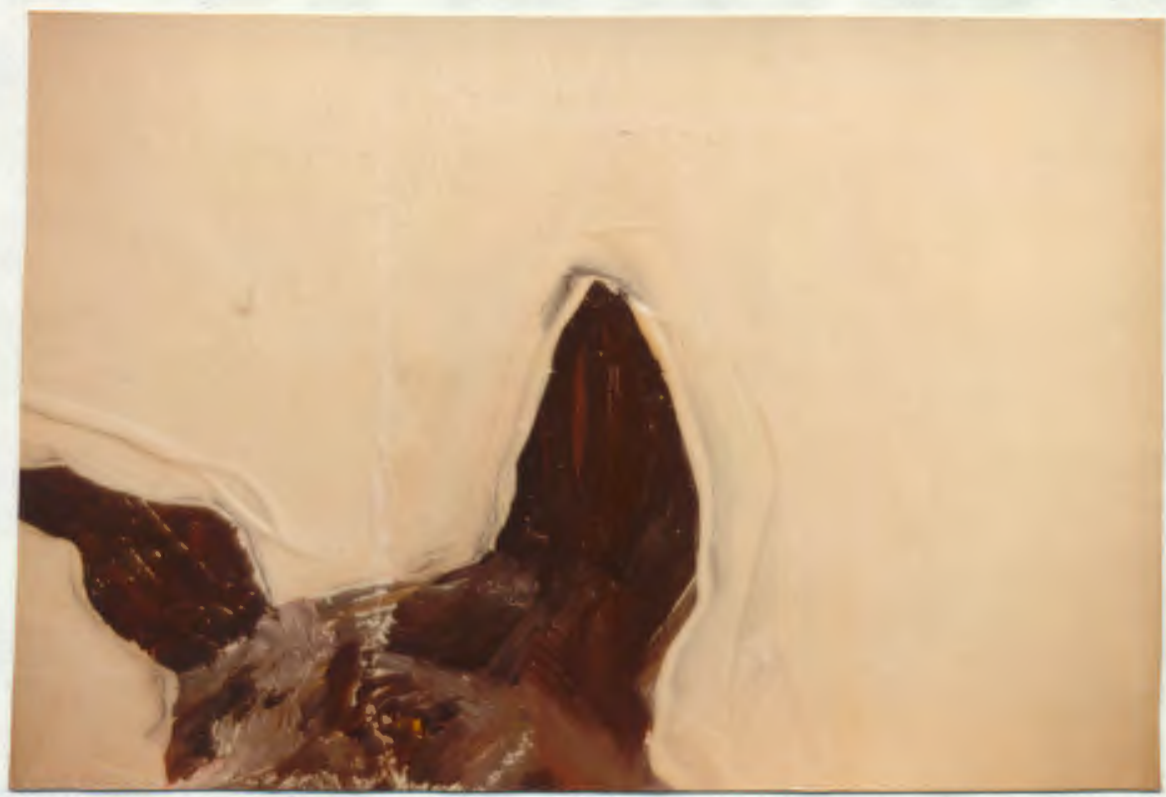

FIGURE X: Blrds, Dogs, Palms, Sun (Deta1l)

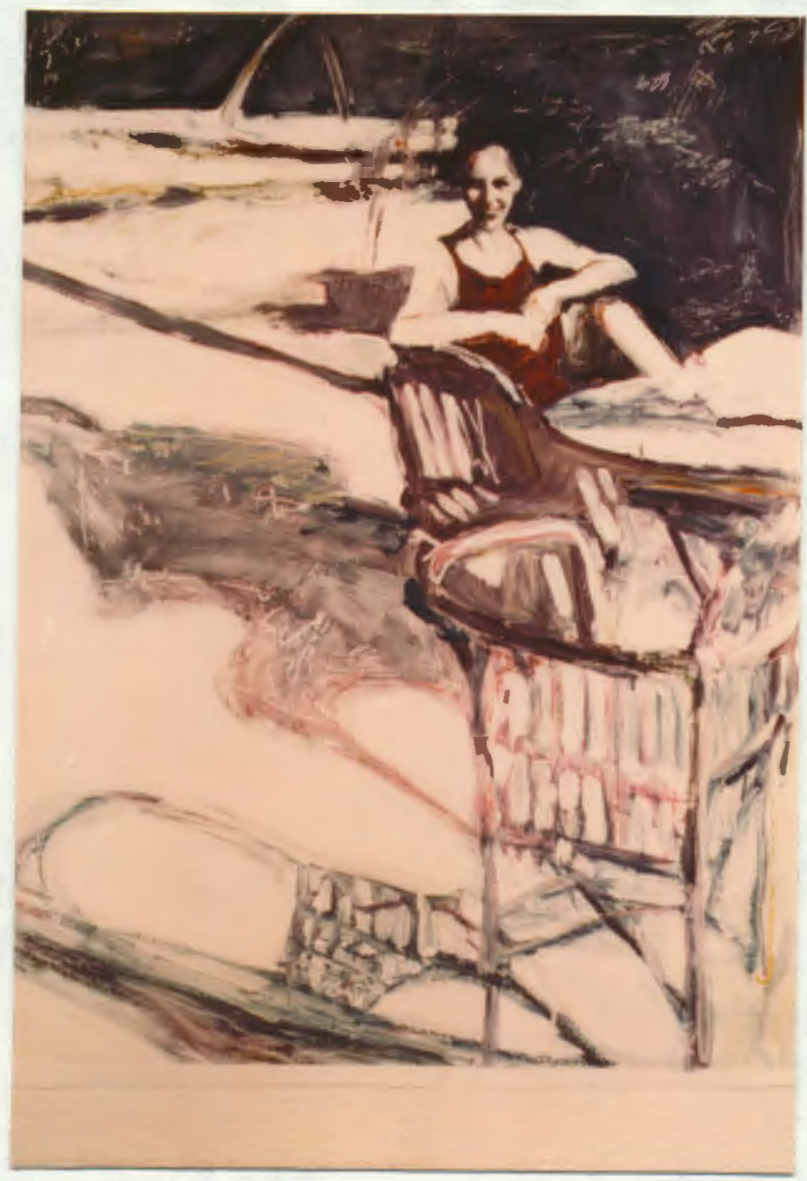

FIGURE IX: Alex's Mother When She Was In Hong Kong 
the painting equivelant for the underlying tension of the times. The English survived by exploiting the Chinese peasants, doing so in an amoral, almost innocent spirit. I like especially "A Moment In IIme" which captures these youthful innocents looking out to sea, forever frozen in their ironic morality like the defense guns of Hong Kong, locked into position against the enemy arriving from the sea (never expecting a land attack through a supposedy impenetrable jungle). The morality and the innocence and the attitudes were swept away by World War II as easily as Hong Kong felI in three days to the Japanese land attack.

It is important to point out a change that occurred in my work when I began to paint from photographs. The paintings took on a precision of detali not found in works done from life. The pieces done from my family album seem especially stiff in this respect. The effects of light in the Hong Kong pieces are as the camera and not the human eye would see them.

Although I feel that it is important to point out these limitations, I feel I should also point out that they were used consciously for various reasons. In the family album pieces I wanted the figures to appear in snap shot sense. These were "snaps" out of life. I hoped a paradox would be set up when these same figures were put in my own fantasy backgrounds.

While most of the Hong Kong series were taken from photographs I incorporated other techniques as well. I took advantage of the distorted way the camera sees filtered light, By breaking up certain areas even more than an unfocused photograph would, I played the resulting confusion against well focused areas to which I wanted to draw attention. As an 


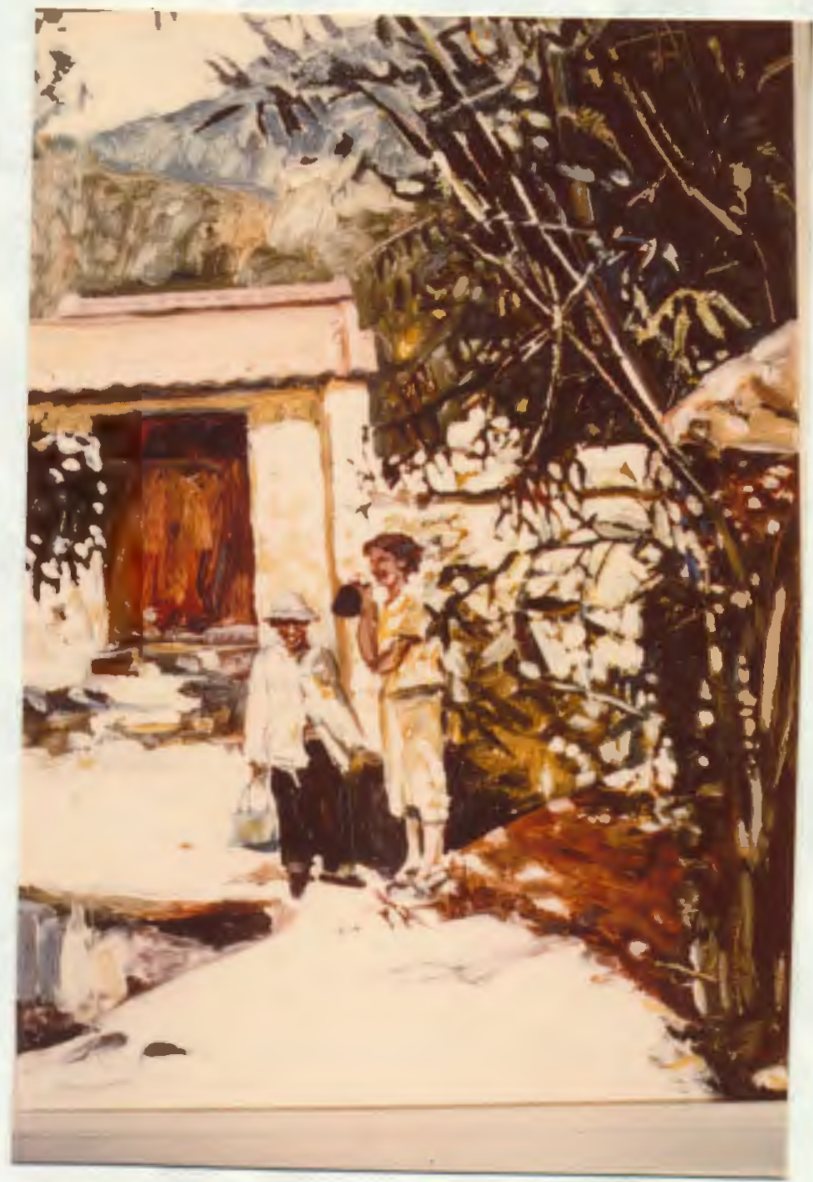

FIGURE XII: Soo Chow Garden

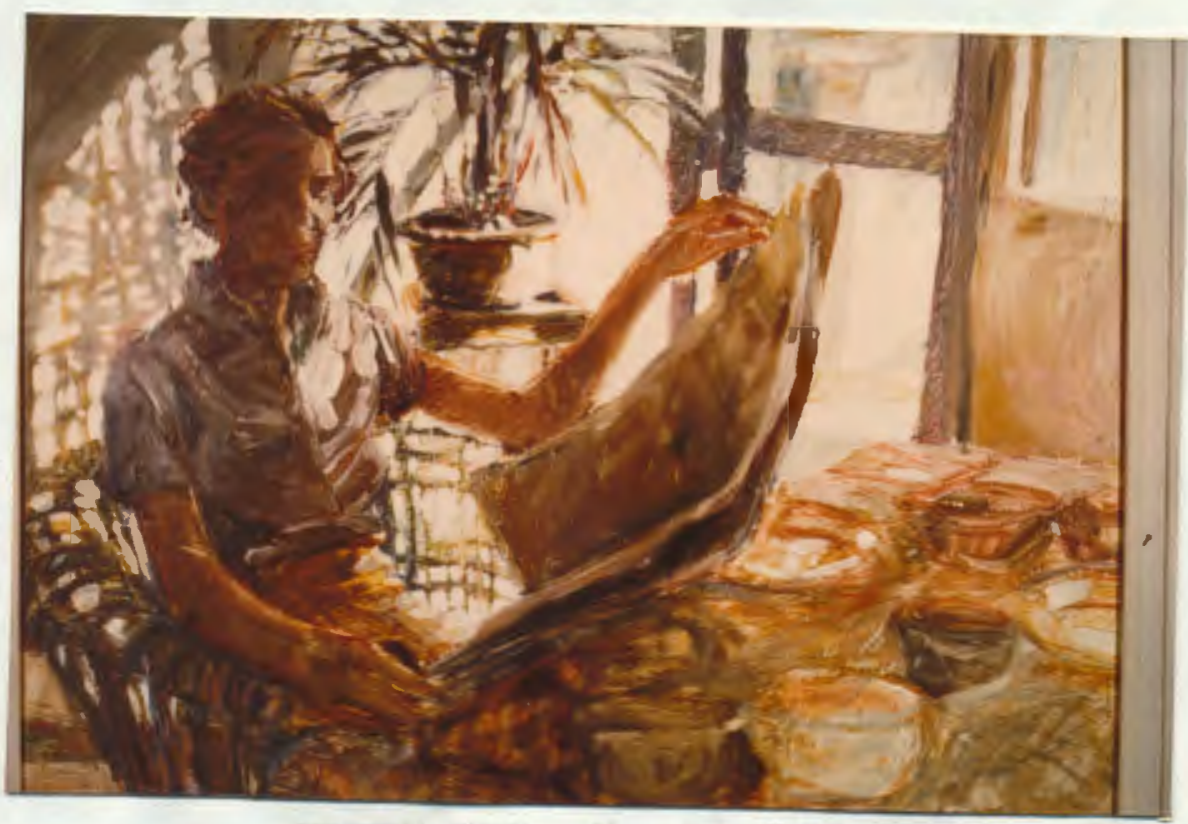

FIGURE XIII: Moming Table 


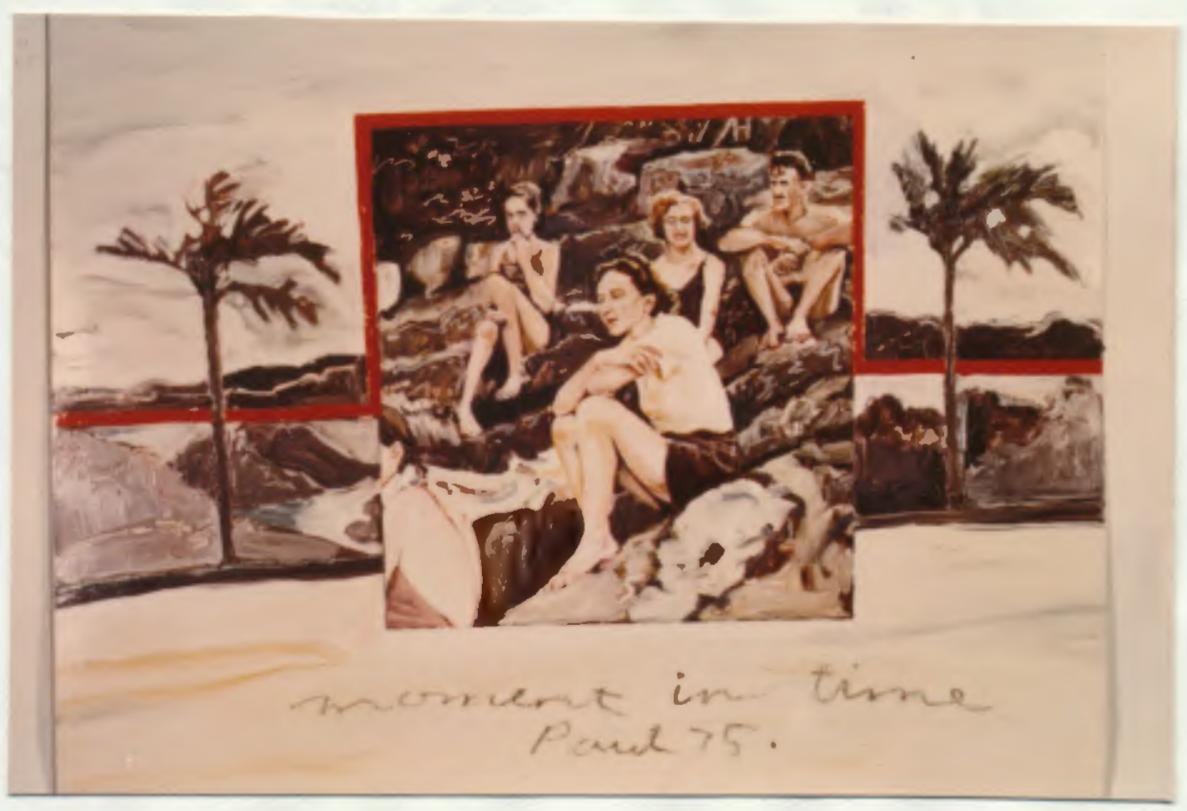

FIGURE XIV: Moment in Time

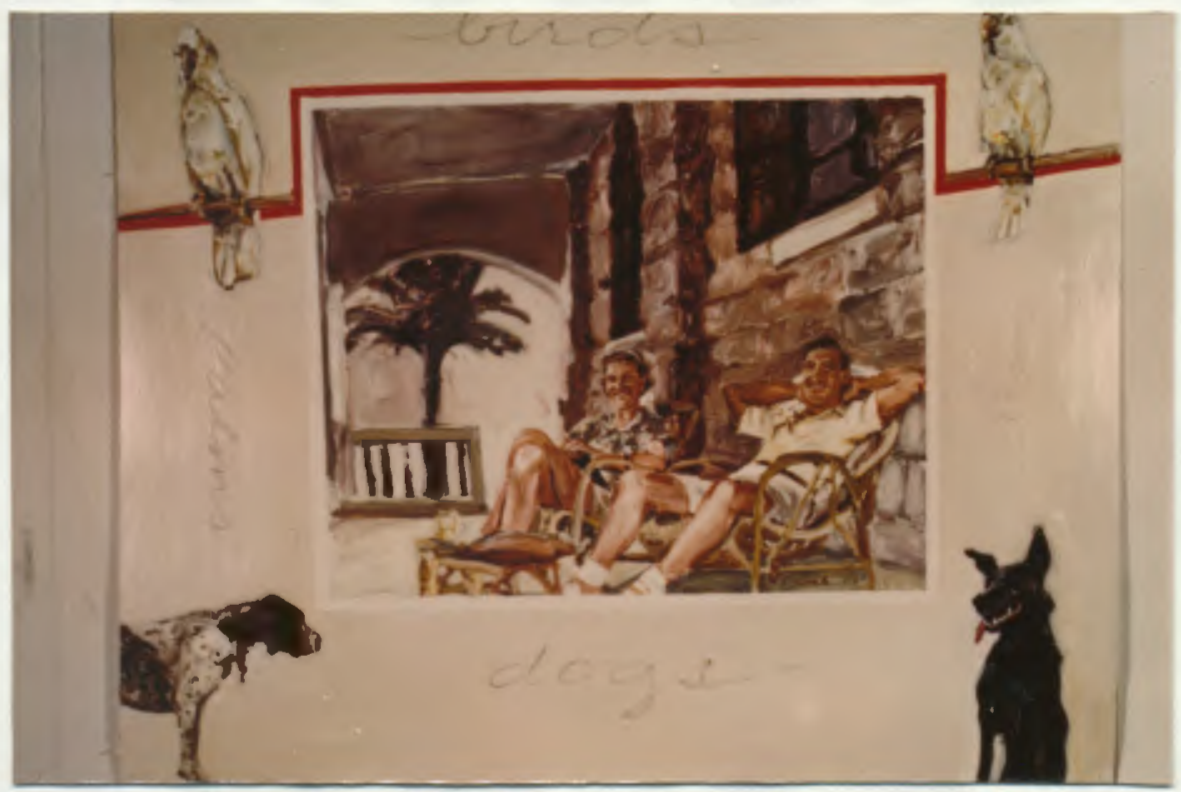

FIGURE XV: Birds, Dogs, PaIms, Sun 
example one can see the clarity in the face of Alex's mother as in "Alex's Mother When She Was In Hong Kong" as opposed to the out of focus distortions in the chair at the bottom of the painting,

Color was another important consideration in my work, All the photographs I worked from were in black and white. As a result, color interpretation became an important part of the mood I was creating in each piece. For the most part I let color selection remain intuitive.

I recognize a distinct difference between colors used in works inspired by my family album and those inspired by Hong Kong photographs. The colors in the former are brighter, reminding me of the colors used in children's art work. The colors in the Hong Kong pieces seem softer. In some cases they remind me of the person depicted. An example of this can be seen in "Alex's Mother When She Was In Hong Kong", where the painting's over all tone is blue. The woman depicted is my husband's mother who uses predominantly blue colors in her dress and house decoration. When I think of her the color blue comes to mind, therefore the use of this color seems most appropriate. In other cases the colors of the Hong Kong pieces remind me of the washed out colors seen in old magazines of the period. A good example of this type of coloring is "Day Rainbow". When I look at old Iife magazines the colors look dull, but leave me with the impression that they were once intense and deep. That's the kind of color I see in "Day Rainbow". It seems most appropriate since the time depicted is Iong past and, for those who were there, the memory is less intense.

Finaliy. the combination of several photographs as seen in "A Moment in Time" and "Birds, Dogs, Palms, Sun" would hopefuily change the meaning of the single viewpoint to a more complex meaningful consideration. 
CONCIUSION

Having arrived at the conclusion of my thesis show one would tend to look back and evaluate where he had been, like a traveller reminiscing after he returned home. I have come from a simple thesis of capturing the common experience to a recognition that a painting, in a very subtle manner, can hopefully communicate a vast panorama of human emotion. Iike the tinkling of wind chimes far away, the viewer reacts to things on a level that he barely realizes, yet which still occur and invite him back for more.

I think this, then, has not been a journey in which I have travelled in a full circle but rather one in which I have developed. Iike the destination on Ken Kesey's bus - "Further" - I feel that I am still developing, exploring and unfolding on a yet to be expressed continuum. The discrete boundaries of saying this is the end of the series is therefore an artificial one, the fact that the thesis is over is not an indication that my work is over. The conclusion therefore is that there is no conclusion. 